Meta

Journal des traducteurs

Translators' Journal

\title{
Self-assessment as an Autonomous Learning Tool in an Interpretation Classroom
}

\section{Yun-Hyang Lee}

Volume 50, numéro 4, décembre 2005

Pour une traductologie proactive - Actes

For a Proactive Translatology - Proceedings

Por una traductología proactiva - Actas

URI : https://id.erudit.org/iderudit/019869ar

DOI : https://doi.org/10.7202/019869ar

Aller au sommaire du numéro

Éditeur(s)

Les Presses de l'Université de Montréal

ISSN

0026-0452 (imprimé)

1492-1421 (numérique)

Découvrir la revue

Citer cet article

Lee, Y.-H. (2005). Self-assessment as an Autonomous Learning Tool in an Interpretation Classroom. Meta, 50(4). https://doi.org/10.7202/019869ar
Résumé de l'article

Cette étude a pour but d'examiner l'utilité de l'auto-évaluation dans les cours d'interprétation. Les étudiants de l'école d'interprétation et de traduction d'un cursus de 2 ans ont participé à cette étude qui consiste à analyser et à évaluer leur propre performance interprétative et à remettre un rapport d'auto-évaluation au professeur. Un questionnaire a été donné par la suite pour déterminer ce que pensent les étudiants de l'auto-évaluation. Les étudiants et le professeur ont tous répondu que l'auto-évaluation jouait un rôle positif car elle permet de déterminer les faiblesses et les points forts de chacun ainsi qu'un exercice ciblé et le monitorat du progrès. Cependant, les étudiants ont également indiqué que l'auto-évaluation nécessite beaucoup de temps et qu'elle est émotivement difficile. Cependant, les étudiants et le professeur ont été unanime à affirmer que l'auto-évaluation apporte une grande contribution pédagogique aux cours. 


\title{
Self-assessment as an Autonomous Learning Tool in an Interpretation Classroom
}

\author{
YUN-HYANG LEE \\ Ewha Womans University, Seoul, Korea \\ ylee@miis.edu
}

\begin{abstract}
RÉSUMÉ
Cette étude a pour but d'examiner l'utilité de l'auto-évaluation dans les cours d'interprétation. Les étudiants de l'école d'interprétation et de traduction d'un cursus de 2 ans ont participé à cette étude qui consiste à analyser et à évaluer leur propre performance interprétative et à remettre un rapport d'auto-évaluation au professeur. Un questionnaire a été donné par la suite pour déterminer ce que pensent les étudiants de l'auto-évaluation. Les étudiants et le professeur ont tous répondu que l'auto-évaluation jouait un rôle positif car elle permet de déterminer les faiblesses et les points forts de chacun ainsi qu'un exercice ciblé et le monitorat du progrès. Cependant, les étudiants ont également indiqué que l'auto-évaluation nécessite beaucoup de temps et qu'elle est émotivement difficile. Cependant, les étudiants et le professeur ont été unanime à affirmer que l'auto-évaluation apporte une grande contribution pédagogique aux cours.
\end{abstract}

\begin{abstract}
This paper explores the usefulness of self-assessment in an interpretation classroom. Students of the Korean-English Program in a two-year graduate school of translation and interpretation were asked to analyze and assess their interpretation performances and submit a self-assessment report to the instructor. Later, a survey was conducted to find out what aspects of self-assessment the students found positive or negative. Based on the responses of the student and the teacher, selfassessment was found to be positive in identifying students' weaknesses and strengths, enable targeted practice, and allow them to monitor their own progresses. But students also found selfassessment to be time-consuming and emotionally draining. However, all students and the instructor agreed that self-assessment was conducive to students' learning in an interpretation classroom.
\end{abstract}

MOTS-CLÉS/KEYWORDS

self-assessment, interpretation, learning tools, Korean

\section{Introduction}

Assessment is one of the critical elements of the learning and teaching experience. In Korea where I have been educated for most of my life, assessment has been used primarily as a screening tool. It was a mechanism in which the teacher had total control, and students had little or no say in the process. The primary purpose of using assessment was to test students' knowledge or ability rather than to facilitate the learning process. From a student's perspective, the term "assessment" meant being tested by the teacher in order to either pass or fail a course or an admissions process.

The tendency to use assessment primarily as a screening tool also applies to the interpreter and translator training environment. Assessment in interpretation training is mostly used to check, evaluate and compare students' interpretation performances against other students, for the purposes of admissions, course examinations, and exit mechanisms. These are, of course, important and critical functions of assessment. However, for assessment to be truly useful in facilitating the learning experience, students need to be more involved in the process.

In order for students to be more involved in the assessment process, students need to learn to utilize assessment themselves. Self-assessment is one way of exposing students to the assessment mechanism. Self-assessment, in the context of interpreter training means students 
taking the initiative in their leaning by analyzing and assessing their own performances, finding strategies for improvement, and monitoring their own progress over time.

Self-assessment also allows students to be in more control of their learning, be responsible for their learning objectives and the learning process. O'Malley and Valdez Pierce (1996:38) state that self-assessment encourages learners to check their own progress and enables them to become more responsible for the direction their learning takes.

Self-assessment is not only important during the training phase of interpretation, but it is critical to professional interpreters as well. In most cases, professional interpreters are responsible for their own quality of performance and do not rely on others for assessment. Because interpreters are often free-lancers, they are left on their own to check their interpretation quality and find measures for improvement on their own. It is true that the ultimate assessment comes from the client. However, clients rarely give feedback to the interpreters, and if they do, it usually comes in the form of complaints. Therefore it is important for students to learn to assess themselves during the training phase so that they can develop an approach that will prove useful in the years to come.

\section{Learner autonomy}

In order for learning to be truly useful, students need to be fully engaged in the learning process. Learning is only possible if learners are autonomous, in other words, if they make the choice to learn and are responsible for their learning (van Lier, 1996). According to Little (1996:204), learner autonomy entails "establishing a personal agenda for learning, taking at least some sense of the initiatives that shape the learning process, and developing a capacity to evaluate the extent and success of one's learning." Chan (2001:285) also describes the autonomous learner as being actively involved at all levels of learning, from goal-setting, defining content and working out mechanisms for assessing achievement and progress and points out that the locus of control for decision-making shifts from teacher to student.

In the context of interpreter training, learner autonomy has to do with developing the ability to check and monitor their quality of interpretation performance, identify characteristics of their performance, develop improvement strategies, as well as design their own roadmap for skill and knowledge acquisition.

Harmer (2004:10), a professor at the Monterey Institute of International Studies, reports of a course where she had second-year interpretation students be more in control of planning, designing, and execution of an interpretation course. Harmer says that "with careful coaching and supervision," students were able to build awareness of the skills they needed to master, to strategize and integrate new skills, and to develop intrinsic motivation through the autonomous learning environment.

My understanding of learner autonomy which I hope to pursue through utilizing selfassessment agrees well with Dickenson (1993:330), who describes autonomous learners as those able to discover how to:

- clearly identify the learning objectives of the course,

- formulate their own learning objectives,

- consciously select and implement appropriate learning strategies,

- identify strategies that are ineffective/inappropriate and substitute others,

- and develop a rich repertoire of effective strategies.

Learner autonomy is not automatic for everyone. Some students may find the new approach threatening, and shy away from active participation (Ho \& Crookall, 1995:242). At the same time, some instructors may also be uncomfortable with the idea of students having more control in the classrooms.

Learner autonomy does not mean that the teacher is excluded from learning. In fact, teachers play an important role of providing students assistance in developing a learning agenda that works for the students. This assistance does not necessarily have to be one way, from teacher to student, but rather a consultation between the learner and the teacher (Tudor, 1996). 
It is essential that all participants play an active part in the autonomous learning process: learner training specially designed to prepare students for what might be a rather new and challenging environment would seem to be the most effective way to anticipate and decrease the likelihood of a negative response (Ficchi, 2002:206-7).

\section{Self-assessment}

\subsection{Students}

Twenty-three students in the Korean-English Program of a two-year graduate school of translation and interpretation were asked to use the self-assessment tool. There were two groups of students; first-year graduate students taking the Introduction to simultaneous interpretation course, and second-year students taking the Consecutive interpretation Korean into English and English into Korean courses.

In order to conduct self-assessments, students' interpretation performances were recorded on cassette tapes. Students were asked to take the cassette tapes home, analyze and assess their performances based on the criteria I had outlined, then to submit a self-assessment report to the instructor. The purpose, format and the mechanics of the self-assessment report were explained in detail to the students. Students were also provided with the speech text from which they were interpreting. This was to allow students to check the accuracy of their own interpretations against the original source text. Students submitted the self-assessment reports within three days after the interpretation performances were recorded.

\subsection{Assessment criteria}

An important aspect of self-assessment is that students clearly understand the criteria based on which they are assessing themselves. In order to achieve consistency, the assessment criteria used in the self-assessment reports were those used by the instructor in the classroom and for examinations.

The assessment criteria are divided into three main categories of Meaning, Language Use, and Delivery. The category of meaning includes aspects of meaning such as meaning errors, additions, omissions, deviations, excessive condensation or generalization that lead to the distortion of the source message. The category of Language Use includes aspects of interpretation that have to do with language such as grammar errors, inappropriate sentence structure, word choices and terminology usage. The Delivery category includes everything that deals with the presentation side of interpretation such as unfinished sentences, back-tracking, pause, hesitation and pronunciation.

Table 1

Assessment categories

\begin{tabular}{|l|l|}
\hline MEANING & $\begin{array}{l}\text { Meaning errors, additions, omissions, deviations, excessive condensations } \\
\text { and generalization that distort the message of the source speech }\end{array}$ \\
\hline $\begin{array}{l}\text { LANGUAGE } \\
\text { USE }\end{array}$ & $\begin{array}{l}\text { Grammar errors, inappropriate sentence structure, word choice, and } \\
\text { terminology errors }\end{array}$ \\
\hline DELIVERY & Unfinished sentence, back-tracking, pause, hesitation, and pronunciation \\
\hline
\end{tabular}

\subsection{An example of self-assessment}

All students completed and submitted the self-assessment reports. As instructed, students analyzed their performances based on the three criteria of Meaning, Language Use, and Delivery in a detailed and comprehensive manner. Students pointed out specific aspects of their performances which they found to be relevant and meaningful.

In order to protect each student's identity, the examples in Table 2 were extracted from three different students' self-assessment reports. Students first analyzed their interpretation 
performances focusing on errors or areas where they had difficulties with. Then they tried to find out the sources of those problems, and come up with strategies for practice to improve the quality of their interpretation performances.

Table 2.

\begin{tabular}{|c|c|}
\hline \multicolumn{2}{|l|}{ Examples } \\
\hline MEANING & $\begin{array}{l}\text { "My biggest problems in the area of 'meaning' are the frequent } \\
\text { omissions of passages and deviations that follow. The source of this } \\
\text { problem is my short memory span and lack of multi-tasking skills. I also } \\
\text { sometimes miss the next passage when I get stuck on a word that I } \\
\text { cannot remember and end up too distressed to concentrate and listen to } \\
\text { the next passage. I need to practice more shadowing to enhance my } \\
\text { multi-tasking skills and do daily memory exercises to increase my } \\
\text { memory span. In addition, I will have to think quicker and be more } \\
\text { decisive on what to do when I am faced with a problem during an } \\
\text { interpreting session so that I will miss less and be able to deliver more of } \\
\text { the context." }\end{array}$ \\
\hline $\begin{array}{l}\text { LANGUAGE } \\
\text { USE }\end{array}$ & $\begin{array}{l}\text { "Language use' is one of the most challenging areas for me. I need to } \\
\text { improve on my vocabulary extensively so that I can use the appropriate } \\
\text { terms and register. I also need to practice matching Korean words with } \\
\text { English words when I memorize them, as it often takes me an extra } \\
\text { second to extricate the meaning of the word and then transfer it to the } \\
\text { target language. As for sentence structure, I will have to practice more } \\
\text { sight translating to develop more varied sentence structures I can readily } \\
\text { employ during a simultaneous interpreting session." }\end{array}$ \\
\hline DELIVERY & $\begin{array}{l}\text { "My voice sounds weak and lacks confidence. I also make frequent } \\
\text { short pauses which make the speech sound choppy and awkward. } \\
\text { Although I am usually conscious of not doing so, I still backtrack a bit. } \\
\text { Most of my pauses and backtracking occur when I get stuck with a word } \\
\text { or am too slow analyzing the text. I will be more aware and make a } \\
\text { conscious effort not to make pauses or backtrack. Also, working on } \\
\text { improving my vocabulary and language transfer skills will help in this } \\
\text { area as well. As for projecting a more confident and cheerful voice, I am } \\
\text { not aware of it when I am in the booth and still have not figured out how } \\
\text { to overcome this problem. I hope to get some advice on this matter from } \\
\text { the professors, but for now the best solution I can think of is doing my } \\
\text { best to be well-prepared so that it can boost my confidence which will } \\
\text { hopefully show in my voice. Lastly, I noticed that my English } \\
\text { pronunciation worsens when I am interpreting. I think that it is still } \\
\text { intelligible, but has a hint of a Korean accent. I will have to be more } \\
\text { careful from now on so that I pronounce everything clearly and } \\
\text { naturally." }\end{array}$ \\
\hline
\end{tabular}

\section{Experiences of self-assessment}

In order to find out students' experiences of the self-assessment, a questionnaire was devised and distributed to the students. Students were asked whether they found self-assessment to be useful, what aspects of it were either positive or negative to their learning. The questionnaire also aimed to provide students with opportunities to make suggestions and comments for the future. 
There were six questions: 1) Did you find the self-assessment to be useful? 2) In what ways was it useful? 3) In what ways, was it not useful? 4) What do you think is the optimum number of self-assessments per semester? 5) What would you suggest changing or improving? 6) Any other comments?

Out of the twenty-three students targeted for survey, nineteen students returned the questionnaire, and all of them replied that they found self-assessment useful in their learning. The features of self-assessment that students found useful were: identification of strengths and weaknesses of their performances, ability to conduct targeted practice, as well as gaining an objective view of their performances. The features of self-assessment that students found to be difficult or felt improvements were needed were: time consuming, emotionally draining, and the fact that weaknesses are not easy to improve even though they may be aware of them.

Students answered that being able to "identify their strengths and weaknesses" was the most important benefit of self-assessment. Students mentioned that they discovered aspects of their performance that they had not noticed before. For example, a student commented that she found English articles to be her most vulnerable point when it comes to English grammar. The student also identified other weak spots such as inappropriate use of conjunctions, sentence structures and production of incomplete sentences. Once she identified these weaknesses, she planned on setting aside time to review these grammar points so that she would make less grammar errors in the future.

Students mentioned that self-assessment allowed them to "listen and analyze their performances in an objective manner." Although students were often encouraged to record and listen to their performances, they admitted that they rarely listened to their own performances in earnest. Utilizing self-assessment as a structured format and a class requirement, students were able to take an objective look at their performances.

Another benefit of self-assessment was that it allowed students to "design and carry out their practices in a more systematic manner." In other words, by analyzing their performances, they were able to identify the weaknesses and failure points in a more specific manner. This enabled students to make more specific goals for their practice. For example, rather than saying, "I am going to improve my performance." their practice goals could be more targeted, such as, "My practice goal for today is to work on eliminating backtracking, i.e. restarting sentences and/or repeating the same words." In the case of the student who had difficulty with English grammar, because she had analyzed and identified the types of grammar errors she made, she was able to narrow her focus to looking into English articles.

In relations to objectivity, some students pointed out that having their oral performances analyzed in a written format was very useful. In interpretation classes, feedback is often given in an oral format, and a "visual inspection of oral performance" seems to have given them new perspectives on their performances.

Students also mentioned the downsides of self-assessment. The negative aspect that was most frequently pointed out was that it was highly "time consuming." One student suggested that analyzing a few paragraphs instead of the whole speech would be more efficient.

Two students commented on the psychological impact of self-assessment and that it was a "very draining experience." This was an unexpected response that needs to be taken into serious consideration in the future. A student commented that she had difficulty remembering why she made the errors due to the "time lag" between the actual interpretation and the time she began to analyze her performance.

When asked what the optimum number of self-assessments should be, the most frequent answer was two to three times a semester. Although most students realized the time-intensiveness of self-assessment, they also commented on the need to do it more than once a semester so that they could monitor their progress over time. 
TABLE 3

Questionnaire and responses from students

\begin{tabular}{|l|l|}
\hline QUESTIONS & ANSWER (NUMBER OF STUDENTS) \\
\hline $\begin{array}{l}\text { 1. Did you find Self-Assessment to be } \\
\text { useful? }\end{array}$ & Yes (16) No (0) \\
\hline 2. In what ways was it useful? & $\begin{array}{l}\text { Identify strengths and weaknesses (7) } \\
\text { Objectivity (4) } \\
\text { Targeted practice (4) } \\
\text { Visual inspection (2) }\end{array}$ \\
\hline 3. In what ways was it not useful? & $\begin{array}{l}\text { Time-consuming (8) } \\
\text { Emotionally draining (2) } \\
\text { Weaknesses but not easy to improve (1) }\end{array}$ \\
\hline $\begin{array}{l}\text { 4. What do you think is the optimum } \\
\text { number of self-assessments per } \\
\text { semester? }\end{array}$ & $\begin{array}{l}\text { Twice a semester (7) } \\
\text { Three times a semester (2) } \\
\text { Four times a semester (2) } \\
\text { Once a semester (1) } \\
\text { Once in two weeks (1) }\end{array}$ \\
\hline $\begin{array}{l}\text { 5. What would you suggest changing } \\
\text { or improving? }\end{array}$ & $\begin{array}{l}\text { Criteria needs to be clearer (3) } \\
\text { Want teacher feedback on Self-Assessment (1) } \\
\text { Time lapse makes it difficult to remember (1) } \\
\text { Want to assess only part of a speech (1) }\end{array}$ \\
\hline $\begin{array}{l}\text { 6. Any Other comments? } \\
\text { Can be applicable for Peer Assessment (1) } \\
\text { Experiment with different formats (1) } \\
\text { Self-Assessment on a regular basis (1) }\end{array}$ \\
\hline
\end{tabular}

\section{Conclusion}

My experience of using self-assessment in the classroom has been positive, and proved selfassessment to be a useful and effective instructional tool. One of the most tangible benefits I found was that self-assessment enabled students to become "more aware of the assessment criteria." Although students were informed of their assessment criteria in classes and after exams, I believe students were really made aware of the criteria after they were asked to conduct self-assessment themselves.

In classes conducted after the self-assessment report, I found students making more specific comments and questions about their performances. They also seemed more comfortable using the terminology used for such as meaning deviations, omissions, word choices etc. This allowed more effective communication to take place in the classroom.

Another advantage that I found important was that I was able to give more "individualized attention" to the students. Students have diverse backgrounds including their language learning experiences, linguistic competences, learning styles and motivations. However due to various limitations, it is not easy for instructors to give individualized attention to each student. By allowing students to identify the individual characteristics of their performances, I was made aware of the specific aspects of their performances which they found to be salient. This allowed me to give more customized feedback to each student rather than the general feedback I used to give to the whole class. As a result, student advising sessions became more productive and effective.

However, there were also difficulties. A critical success factor for self-assessment is for both the student and the teacher to have a clear understanding of the assessment criteria. This was more easily said than done. Although I have been using the same assessment criteria in class and for exams, and explained them again in detail before self-assessment, students still listed "having clearer assessment criteria" as one of the biggest challenge for them. 
This is somewhat understandable considering the fact that students had no real training or experience using these criteria. Perhaps this is all the more reason to involve students in the assessment process so that they become more familiar with the criteria used by the instructors. Communicating these criteria clearly requires an ongoing and conscious effort on the part of the teachers.

There also is a need to find better formats for assessment. The format used in this case was based on the three categories of Meaning, Language Use, and Delivery. Certain aspects of these categories overlap which created confusion among the students. There is also the issue of "time lag" between the actual interpretation and the analysis of the performance, i.e., the writing of the self-assessment report. A student suggested conducting the self-assessment immediately after the interpretation. Other options worth exploring may include utilizing Think-Aloud-Protocol (TAP), a short verbal report format, or conducting small group discussions.

There was also a suggestion that this structured approach be used for peer assessment. A student commented that she had difficulty providing accurate and effective feedback to her peers during group study. Peer assessment is an area that we need to look into seriously since interpretation students spend much time in group studies. I would recommend that students start with their own self-assessment first before moving on to peer assessment. By doing their own assessment first, students will be more familiar with the concept and the mechanics before assessing someone else's performance.

A critical aspect of self-assessment is that students become autonomous in their learning. Compared to the traditional type of a teacher-centered instruction, students need to invest time, get more involved in and outside the classroom, and take responsibility of their learning process. This is not easy for everyone. In my classes where the majority of students come from Korea, students are more familiar and comfortable with the teachers taking charge of their learning. Therefore, it was essential for students to understand the purpose behind their taking more responsibility in the learning process.

Learning is a life-long process. This applies to all types of learning since there cannot be mastery or perfection of a skill or knowledge. Learning in school, although important, is only a portion of the overall learning that takes place in one's lifetime. The more independent and responsible learners are with their learning opportunities, the more successful they will be in their learning experience.

\section{REFERENCES}

Chan, V. (2001): "Learning Autonomously: The Learner's Perspectives," Journal of Further and Higher

Education 25-3, pp. 285-300.

Dickenson, L. (1995): “Autonomy and Motivation. A Literature Review,” Systems 23-2, pp. 165-174.

FICCHI, B. (1999): “ Learning Consecutive Interpretation: an Empirical Study and an Autonomous Approach,” Interpreting 4-2, pp.199-218.

HARMER, J. (2004): "Beyond Borders: Expanding on Traditional Classroom Lessons Through Autonomous Learning," unpublished.

Ho, J. and D. CROOKALL (1995): "Breaking with Chinese Cultural Traditions: Learner Autonomy in English

Language Teaching," System 23-2, pp. 235-243.

KENNY, B. (1993): “For More Autonomy,” System 21-4, pp. 431-442.

LiTTLE, D. (1995): "Learning as Dialogue: the Dependence of Learner Autonomy on Teacher Autonomy,” Systems 23-2, pp. 175-181.

O’Malley, J.M. and L. VAldez Pierce (1996): Authentic Assessment for English Language Learners: Practical Approaches For Teachers, Reading, Mass., Addison-Wesley Pub. Co.

TUdoR, I. (1996): Learner-centeredness as Language Education, New York, Cambridge University Press. VAN LIER, L. (1996). Interaction in the Language Curriculum: Awareness, Autonomy, and Authenticity. London, Longman. 